\title{
Effects of organic fertilizer application on yield, soil organic matter and porosity on Kilis oil olive variety under arid conditions
}

\author{
Meryem KUZUCU \\ Kilis 7 Arallk University Technical Science Vocational School, Department of Plant and Animal Production, \\ Horticulture Programme. 79000 Kilis, Turkey
}

Corresponding author: mrymgunes@gmail.com

\begin{abstract}
Plant and soil must use fertilizer in order to maintain productivity in agricultural production. High-oil olive varieties are grown which has specific high economic value and locally in Kilis city under dry conditions. Kilis oil olive variety has produced without fertilization in dry conditions, in the city. It is necessary to fertilizer the soil and plant in order to ensure sustainability in agricultural production. If agricultural production made from nonfertilizer of method, soil physical conditions are degraded becomes poor and low yield is emerged. In this study, Kilis olive oil variety which is important variety in our country, they are 38 years old and $25 \mathrm{~kg} /$ tree, $50 \mathrm{~kg} / \mathrm{tree}$ and $75 \mathrm{~kg} /$ tree fertilizer was applied to them. As a result of the study, soil porosity values ranged from $36.2 \%$ and $55.8 \%$. The highest porosity value was measured from $75 \mathrm{~kg} / \mathrm{tree}$ organic fertilizer application. Soil organic matter was determined to be $2.28 \%$ with the help of organic fertilizer while it was $0.95 \%$ with traditional application. The highest olive yield was obtained from $75 \mathrm{~kg} /$ tree organic fertilizer application. Close results were obtained at 50 and $75 \mathrm{~kg} /$ tree fertilizer doses therefore $50 \mathrm{~kg}$ fertilizer dose is recommended for olive producers.
\end{abstract}

Keywords: Dry agriculture, organic fertilizer, soil porosity, organic matter, yield.

\section{Introduction}

Sustainable agricultural production takes place only with a fertile soil. In order to soil quality improving, we need to nutrition, protect and soil manage to prevent deterioration for future using with the most suitable functions. Soil physical conditions need to be improved to provide soil fertility persistence. Organic matter using improves both soil physical conditions and crop yield in agriculture soils. When the total porosity value of the soil is low the clearance rate of the soil decreases, plant roots aeration decrease therefore, the plant's growth and yield is reduced. Due to the lack of precipitation and very high summer temperature soil organic matter content is low in the arid regions. It is known that with organic matter addition in to the soil, improves the soil physical, chemical and biological conditions. Soil aggregation improving, soil aeration conditions and hence development of plant roots is increasing. Increased soil organic matter, soil porosity and thus leads to increased crop yields. Since B.C. 4000 cultivation has been made olive proved to source of many myths within the historical development. Olive motherland is also including Southeastern Anatolia Region Upper Mesopotamia and South Front Asia that takes place in the inscriptions and ancient civilizations holy books (Özkaya et al.2004). Olives are grown in Aegean and Marmara regions, especially in Southeastern Anatolia and also fewer amounts in Black Sea region in Turkey. Our country productions' is evaluated $73.6 \%$ of oilseed as $26.4 \%$ edible 
table. Alagöz et al. (2006) have determined an organic fertilizer using to increase soil organic matter levels improves the soil physical, chemical and biological properties. Organic fertilizers consisting of materials of vegetable and animal origin are very important for plant growth and soil fertility. Brohi et al. (1995) found that organic acids, resulting from the decomposition of organic matter, increased the usefulness of plant nutrients by dissolving the minerals. Wong et al. (1999), in the study of organic farming, different amount of soil $(0,10,25,50$ and 75 tons / ha) was applied, manure, manure and total organic matter, macro $(\mathrm{N}, \mathrm{P}, \mathrm{Mg}, \mathrm{Na}, \mathrm{Ca}$ and $\mathrm{K})$ and micro $(\mathrm{Cu}, \mathrm{Zn}$ and $\mathrm{Mn})$ nutrients has increased. Doran et al. (2008), using 20-30 kg/tree manure in product years and was found be insufficient for olive trees in Derik town, Mardin province. If $50-60 \mathrm{~kg}$ of manure is mixed in the soil, he said, it can eliminate nutritional problems, increase fruit and fat ratio. In order to increase the soil organic substance olive pruning waste can be added to the soil. This is a very useful application for soil physical, chemical and biological properties (Bellitürk et al. 2018). The aim of ensure sustainability in agriculture we need to keep the soil fertility (Bellitürk, 2016). The yield and quality of olive groves are generally low in our province. The decrease in productivity is due to periodicity, ecological, cultural factors and drought. In this study, different doses farm manure applied in olive trees it is aimed to reveal the relationship with yield soil porosity and changes in organic matter content under dry conditions. Olive producer's productions are realized without fertilization and only use soil tillage under dry conditions in our province. Such soil using has caused soil inefficiency. As a result of these soil organic matter decomposes, soil porosity values decreases, soil physical conditions deteriorate, plant roots can't reach the their needed water and nutrients and therefore the soil becomes poor and efficiency is reduced. In this study, soil organic matter, porosity and yield increase were investigated by feeding the soil and trial subjects in the study have been more successful than traditional farmers. High productivity and quality is obtained however, as a result of plants adequate and balanced nutrition in agricultural production. It was determined that organic fertilizers are important and necessary to ensure the continuity of agricultural production.

\section{Material and Methods}

\section{Site Properties}

This study was carried out between 2014-2015 years and consisting Kilis oil olive variety in farmer's garden in Kilis province. Kilis has red-brown soils. Soil lime content is high, organic matter amount is low and its texture class is mostly clay loam (CL) soils. Kilis has a Terrestrial and Mediterranean climate. General characteristics of climate; summers are very hot and dry, winters are warm and rainy. Average annual rainfall is $485.7 \mathrm{~mm}$ and average annual temperature varies between $16,5-17,8^{\circ} \mathrm{C}$. Research area soil properties are given in Table 1.

Table 1. Some soil physical and chemical properties of treatment areas

\begin{tabular}{ccccccccccc}
\hline $\begin{array}{c}\text { Depth } \\
(\mathrm{cm})\end{array}$ & $\begin{array}{c}\text { Texture } \\
\text { Class }\end{array}$ & Stone $(\%)$ & Clay $(\%)$ & Loam $(\%)$ & & $\begin{array}{c}\mathrm{pH} \\
\text { Density } \\
\left(\mathrm{g} / \mathrm{cm}^{3}\right)\end{array}$ & $\begin{array}{c}\mathrm{CaCO}_{3} \\
(\%)\end{array}$ & $\begin{array}{c}\mathrm{P}_{2} \mathrm{O}_{5} \\
(\mathrm{~kg} / \mathrm{da})\end{array}$ & $\begin{array}{c}\mathrm{K}_{2} \mathrm{O} \\
(\mathrm{kg} / \mathrm{da})\end{array}$ & $\begin{array}{c}\mathrm{O} \text { Organic } \\
\text { matter } \\
(\%)\end{array}$ \\
\hline $0-30$ & $\begin{array}{l}\text { Clay } \\
\text { loam }\end{array}$ & 35.66 & 39.08 & 25.26 & 7.70 & 1.25 & 30.00 & 2.12 & 123.1 & 1.02 \\
$30-60$ & $\begin{array}{l}\text { Clay } \\
\text { loam }\end{array}$ & 38.70 & 37.10 & 24.20 & 7.74 & 1.26 & 30.40 & 1.35 & 51.8 & 0.93 \\
$60-90$ & $\begin{array}{l}\text { Clay } \\
\text { loam }\end{array}$ & 40.12 & 37.26 & 22.62 & 7.72 & 1.25 & 35.20 & 1.07 & 58.7 & 0.85 \\
\hline
\end{tabular}

\section{Methods}

\section{Trial pattern and topics}

Three different farm fertilizer doses were applied according to trial design of randomized plots with 3 replications. There are 3 trees in each subject and a total of 36 trees in the experiment. Farm manure has used in September in $25 \mathrm{~cm}$ soil depth before precipitation start in both years. 
G0: Traditional farmer application (without fertilization, control)

$\mathrm{G} 1: 25 \mathrm{~kg} / \mathrm{tree}$ farm manure

$\mathrm{G} 2: 50 \mathrm{~kg} /$ tree farm manure

G3: $75 \mathrm{~kg} /$ tree farm manure

- Some characteristics of farm manure are given in Table 2.

Table 2. Some physical and chemical properties of farm fertilizer.

Farm Manure

\begin{tabular}{ll}
\hline $\mathrm{EC}(\mathrm{mS} / \mathrm{cm})$ & 0,56 \\
$\mathrm{pH}$ & 7.70 \\
Organic Matter $(\%)$ & 15.20 \\
$\mathrm{~N}(\%)$ & 1.02 \\
$\mathrm{P}(\%)$ & 0,46 \\
$\mathrm{~K}(\%)$ & 1.38 \\
$\mathrm{C} / \mathrm{N}$ & 7.56 \\
$\mathrm{Ca}(\%)$ & 3.60 \\
$\mathrm{Mg}(\%)$ & 0.92 \\
$\mathrm{Zn}(\mathrm{ppm})$ & 176 \\
$\mathrm{Mn}(\mathrm{ppm})$ & 235 \\
\hline
\end{tabular}

\section{Research Applications}

The method applied by our farmers in the application of traditional farmers. Only soil tillage has been carried out in Control application. Olive producers use soil tillage at least 4 times during the growing season in our province. Soil tillage has been carried out 4 times in this olive garden during this study. Totally 3 different doses farmyard manure were applied in fertilization subjects.

\section{Analysis and evaluation methods}

Soil porosity and organic matter analyzes were performed in soil samples taken from the olive orchard in Jun when precipitation finish in both research years. The amount of organic matter was calculated in soil samples taken from each subject (Tüzüner, 1990). Porosity measurements; \% $\mathrm{n}=(1-\mathrm{db} / \mathrm{dp}) \times 100$ formula (Bahtiyar, 1996). Per tree olive yield during harvest and 100 olive fruit weight was calculated.

\section{Statistical Analysis}

The results were compared subjected to variance analysis (Açıkgöz et al. 1993).

\section{Results}

\section{Total Porosity}

Soil tillage is very important in arid areas. Soil porosity is closely related to soil tillage. Vertical soil tillage carried out to slope in order to rainwater collected in soil profile in non-irrigation olive orchard. Soil treatment should be done at a minimum level to meet the need to protect soil water. Second crop silage corn production technical and economic determination has used different tillage methods in their work, the highest silage maize yield obtained from traditional tillage method (Baran et al. 2014). According to trial subjects as applied fertilizer doses increased, soil total porosity value increased. Organic matter decomposed in soil, has achieved aggregation and has benefited soil porosity. Therefore, total porosity value increased in all subjects in the second year of experiment in soil both depths compared to the first year. The porosity value has increased at $0-30 \mathrm{~cm}$ and decreased in $30-60 \mathrm{~cm}$ soil depth (Table.3). There is no difference in porosity values between the two years in the control, while the porosity value is high at $0-30 \mathrm{~cm}$ depth and decreases at $30-60 \mathrm{~cm}$ depth. 
Table 3. Organic fertilizer doses and total porosity values.

\begin{tabular}{|c|c|c|c|}
\hline \multirow[t]{3}{*}{ Treatments } & & & \\
\hline & \multicolumn{3}{|c|}{ Total Porosity (\%) } \\
\hline & Depth $(\mathrm{cm})$ & First year & Second year \\
\hline GO- Traditional application & $0-30$ & $39.7 \mathrm{bc}$ & $38.6 \mathrm{c}$ \\
\hline (Control) & $30-60$ & $37.5 \mathrm{c}$ & $36.2 \mathrm{c}$ \\
\hline G1- 25kg/tree Farmyard & $0-30$ & $41.5 b$ & $44.3 b$ \\
\hline Manure & $30-60$ & $38.4 \mathrm{bc}$ & $40.7 b c$ \\
\hline G2- 50kg/tree Farmyard & $0-30$ & $42.2 \mathrm{~b}$ & $47.2 \mathrm{~b}$ \\
\hline Manure & $30-60$ & $39.6 \mathrm{bc}$ & $43.6 \mathrm{~b}$ \\
\hline G3- $75 \mathrm{~kg} /$ tree Farmyard & $0-30$ & $52.40 \mathrm{a}$ & $55.8 \mathrm{a}$ \\
\hline Manure & $30-60$ & $45.3 b$ & $52.5 \mathrm{a}$ \\
\hline CV (\%) & & 1,45 & 1,12 \\
\hline LSD & & $0.17 *$ & $0.12 *$ \\
\hline
\end{tabular}

Values are 3 replication averages.

* There was no difference between $\mathrm{p}<0.01$ levels in the same group.

The highest value of $75 \mathrm{~kg} /$ tree farm manure application was determined as $55.8 \%$ at $0-30 \mathrm{~cm}$ depth. The lowest porosity value was obtained from the $30-60 \mathrm{~cm}$ depth of the control subject with $36.2 \%$. The porosity results obtained from the $50 \mathrm{~kg}$ and $75 \mathrm{~kg}$ farm manure doses per tree were found to be close to each other. When Table 3 is examined soil total porosity values were found be higher of 0-30 $\mathrm{cm}$ depth than the $30-60 \mathrm{~cm}$ soil depth.

\section{Soil organic matter changes}

Soil organic matter is quite low at non-irrigation agriculture production in this arid soils that having high temperature and evaporation. Organic fertilization is extremely important for our olive orchards. The highest soil organic matter value (2.28\%) was found by applying $75 \mathrm{~kg}$ farm manure per tree. The lowest organic matter obtained from control application with $0.95 \%$. While $25 \mathrm{~kg} /$ tree organic fertilizer application caused yield increasing compared to traditional application, it didn't contribute significantly to soil organic matter content (Table 4).

Table 4. Soil organic matter changes $(\%)$.

\begin{tabular}{lll} 
& \multicolumn{2}{c}{ Average Organic Matter $(\%)$} \\
\cline { 2 - 3 } Treatments & First Year & Second Year \\
\hline Traditional application & $0.98 \mathrm{bc}$ & $0.95 \mathrm{bc}$ \\
$25 \mathrm{~kg} /$ tree Farmyard Manure & $1.18 \mathrm{~b}$ & $1.24 \mathrm{~b}$ \\
$50 \mathrm{~kg} /$ tree Farmyard Manure & $1.59 \mathrm{a}$ & $1.86 \mathrm{a}$ \\
$75 \mathrm{~kg} /$ tree Farmyard Manure & $2.16 \mathrm{a}$ & $2.28 \mathrm{a}$ \\
\hline
\end{tabular}

CV \% 1.12

Values are 3 replicates averages.

No difference was found between the averages indicated with the same letter in the same group as $\mathrm{p}<0.01$.

Soil organic matter showed a linear increase with the applied fertilizer doses. $50 \mathrm{~kg} /$ tree with $75 \mathrm{~kg} / \mathrm{tree}$ farm manure application soil organic matter content increasing has found relatively close to each other. (Table 4, Figure 1). Therefore, if our farmers do not find $75 \mathrm{~kg}$ of farm manure per tree, they can provide soil fertility by using 50kg farmyard fertilizer. Thus, it will be understood that the increase in yield will be achieved compared to the traditional production in the province. The application of organic fertilizer has increased the content of organic matter in the soil. Increase of soil organic matter is the meaning of increase of soil fertility and quality (Bellitürk, 2018). 


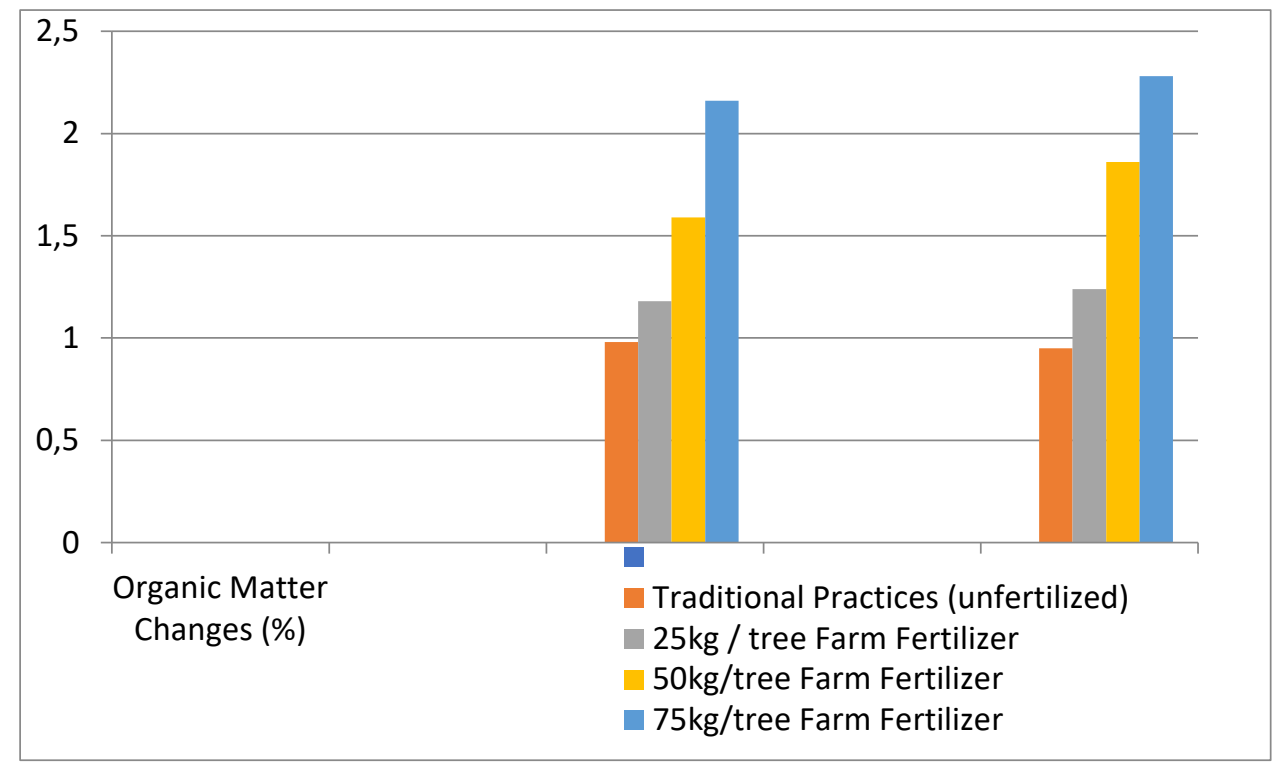

Figure 1. Fertilizer dose soil organic matter content exchange (2014-2015).

Bellitürk et al. (2012) reported that $94 \%$ Turkey soils are poor in terms of organic matter, must spread the fertilizer and green manure organic fertilizer use and our farmers should be encouraged to use. These research results are support and consistent with our findings obtained from this study.

\section{Yield}

Applied fertilizer doses were effective on the yield per tree and 100 fruit weight $(\mathrm{p}<0.01)$. Significant yield increases were obtained in olive yield according to traditional application (Table 5). In terms of yield values 4 groups were formed as a result of statistical analysis and farmer application with nonfertilizer was located in the lowest yield level group. The highest average olive yield was obtained from $75 \mathrm{~kg} /$ tree farm manure application with $67.25 \mathrm{~kg} /$ tree. The lowest average yield was taken from the control application with $20.16 \mathrm{~kg} / \mathrm{tree}$.

Table 5. Fertilizer dose and olive yield value.

\begin{tabular}{|c|c|c|c|c|c|c|}
\hline \multirow[b]{2}{*}{ Treatments } & \multicolumn{3}{|c|}{ Yield kg/tree } & \multicolumn{3}{|c|}{100 Fruit Weight $(\mathrm{g})$} \\
\hline & $\begin{array}{l}2014 \text { year } \\
\text { (product year) }\end{array}$ & $\begin{array}{c}2015 \text { year } \\
\text { (periodicity } \\
\text { year) }\end{array}$ & Average & $\begin{array}{c}2014 \text { year } \\
\text { (product } \\
\text { year) }\end{array}$ & $\begin{array}{c}2015 \text { year } \\
\text { (periodicity } \\
\text { year) }\end{array}$ & Average \\
\hline $\begin{array}{l}\text { G-O kg/ağaç } \\
\text { No-fertilizer }\end{array}$ & 26.20 & 14.12 & $20.16 \mathrm{c}$ & 265 & 286 & 275.5 \\
\hline $\begin{array}{l}\text { G1- } 25 \mathrm{~kg} / \text { tree } \\
\text { Farmyyard Manure }\end{array}$ & 49.50 & 24.65 & $37.07 \mathrm{~b}$ & 269 & 277 & 273 \\
\hline $\begin{array}{l}\mathrm{G} 2-50 \mathrm{~kg} / \text { tree } \\
\text { Farmyard Manure }\end{array}$ & 75.30 & 44.20 & $59.75 \mathrm{ab}$ & 276 & 297 & 286.5 \\
\hline $\begin{array}{l}\mathrm{G} 3-75 \mathrm{~kg} / \text { tree } \\
\text { Farmyard Manure }\end{array}$ & 82.10 & 52.40 & $67.25 \mathrm{a}$ & 282 & 298 & 290 \\
\hline Average & 58.27 & 33.84 & CV\% 1.26 & & 289.5 & 281.25 \\
\hline
\end{tabular}

Values are 3 repetition averages.

Differences between means are significant at $\mathrm{p}<0.01$.

As shown in Table 5, a linear relation was found between applied fertilizer doses and olive yield. As organic fertilizer doses increase, olive yield per tree also increases (Doran et al. 2006) supported our findings. Due to the olive periodicity, 2014 product year olive yield values are higher than 2015 periodicity year. There was no difference statistically 100 fruit weight in both years. Changes were 
observed in terms of 100 fruit weight between two years. Since product year trees gives full fruit therefore fruits become small and light. In the periodicity year the situation is the opposite. Olive trees give less fruit and olive fruit have been big and heavy (Table5). According to the year's average, $50 \mathrm{~kg}$ and $75 \mathrm{~kg}$ per tree farm fertilizer application has been found to be close to each other. Our farmers will be able apply any of these two doses to increase olive yields according to the traditional application.

\section{Discussion}

The importance of organic fertilizers and organic production is increasing day by day. Olive producers who continue production without fertilization should know that organic fertilizer applications necessary for soil fertility increasing as well as sustainability agricultural production in agricultural soils. Many studies show that organic fertilizers maintain leaves nutrient content during the plant growth, it prevents fruit spilling and can increase olive yield (Hassan et al. 2015). As a result of this study, organic fertilization has increased soil porosity and supported root growth and increased soil organic matter thus, increased efficiency in olive production. Kilis province olive producers can use natural, eco-friendly and useful farm manure before the rainfall in September they able to provide soil fertility long years. Organic fertilization is also important to eliminate drought effects in this non-irrigation agriculture soils. Farmers can easily find farm manure in their villages. These useful organic fertilizers using should become widespread. It is recommended to our farmers, average $50 \mathrm{~kg} /$ tree farm manure applications have provided soil fertility, sustainability and crop efficiency in their average 50 years old and dry olive orchards.

\section{Acknowledgements}

We would like to thank Agricultural Consultant, Agricultural Engineers and Olive Producer Farmers for their support.

\section{References}

Açıkgöz, N., M.E. Akkaş, A. Moghaddam ve K. Özcan. 1993. Tarist PC'ler için istatistik ve kantitatif genetik paketi. Uluslararası Bilgisayar Uygulamaları Semp. 133, 19 Ekim 1993 Konya.

Alagöz, Z., Yılmaz E., Öktüren F. 2006. Organik materyal ilavesinin bazı fiziksel ve kimyasal toprak özellikleri üzerine etkileri. Akdeniz Ünv. Zir. Fak. Dergisi, 19(2): 245-254

Bahtiyar,M.,1996. Toprak Fiziği. Trakya Üniversitesi Tekirdağ Ziraat Fakültesi Yayın No:260. Tekirdağ.

Baran, M.F. Durgut,M.R., Kayhan,İ.E., Kurşun,İ., Aydın,B. And Bayhan,Y. 2014. Determintion of Different Tillage Methods in Terms of Tchnically and Economically in Second Crop Maize for Silage. Journal of Tekirdağ Agricultural Faculty 2014 11(2). P.11-20.

Bellitürk K., Şinik, E., Karakaş, Ö. 2012. Study Based On Determination to Content of Some Elements of Plant Nutrition In Acid Soil Which Is Placed In Edirne. SAÜ Fen Edebiyat Journal (2012-1) pages: 207-215.

Bellitürk, K., 2016. Sürdürülebilir Tarımsal Üretimde Katı Atık Yönetimi İçin Vermikompost Teknolojisi. Çukurova Tarım ve Gıda Bilimleri Dergisi, 31 (3): 1-5 (Özel Sayı), Adana.

Bellitürk, K., Göçmez, S., Turan, H.S., Bağdatlı, M.C. ve Üstündă̆, Ö., 2018. Zeytin Budama Artıklarının Vermikompost Olarak Değerlendirilmesi: Makro Elementler. Uluslararası Tarım, Çevre ve Sağlık Kongresi, 2628 Ekim 2018, s: 2028-2034, Aydın 
Bellitürk, K., 2018. Vermicomposting in Turkey: Challenges and Opportunities in Future. Eurasian Journal of Forest Science. 6 (4): 32-41.

Brohi, A., A. Aydeniz ve M.N. Karaman. 1995. Toprak verimliliği. Gaziosmanpaşa Üniv. Ziraat Fak. Yayınları 5. Kitaplar Serisi, 5.

Doran, I., E. İsen, B. Pekkolay ve M. Mungan. 2006. Mardin yöresi zeytinliklerini beslenme durumunun tespiti. Dicle Üni. Ziraat Fak. Diyarbakır.

Hassan, A.M., N. Abd-Alhamid, B.M.A. Rawheya, H.S.A. Aly Hassan, A.A. Abdelhafez and L.F. Haggag. 2015. Effect of organic and bio-fertilization on yield and quality of "Manzanillo" olives. Middle East J. Agric. Res., ISSN 2077-4605. 4(3): 485-493.

Özkaya, M.T. 2004. Gemlik zeytin (olea europaea 1.) çeşidinde farklı dönemlerde uygulanan bazı yaprak gübrelerinin meyve verim ve kalitesi üzerine etkileri. Tarım Bilimleri Dergisi, 10(3): 353-357.

Tüzüner,A., 1990 Toprak ve Su Analiz Laboratuvarı El Kitabı. KHGM Yayınları. Ankara.

Wong, J.W.C., M.A., K.K., Fang, K.M, Bcheung, C. 1999. Utilization of Manure Compost for Organic Farming in Hong Kong. Bioresource Techn., 67: 43-46.

Submitted: 10.01.2019 - Accepted: 03.02.2019 